\title{
Reviving, In Vitro Differentiation, Development, and Micropropagation of the Rare and Endangered Moss Bruchia vogesiaca (Bruchiaceae)
}

\author{
Marko Sabovljević, Milorad Vujičić, and Jasmina Šinžar Sekulić \\ Institute of Botany and Garden, Faculty of Biology, University of Belgrade, \\ Takovska 43, 11000 Belgrade, Serbia
}

\section{Jose Gabriel Segarra-Moragues}

Centro de Investigaciones sobre Desertificación (CIDE-CSIC-UV-GV), C/Carretera de Moncada-Náquera Km 4.5, Apartado Oficial, E-46113, Moncada (Valencia), Spain

\section{Beata Papp \\ Botanical Department, Hungarian Natural History Museum, Budapest, Pf. 222., 1476, Hungary}

\section{Marijana Skorić}

Institute for Biological Research Sinisa Stankovic, University of Belgrade, Bul. Despota Stefana 142, 11000 Belgrade, Serbia

\section{Luka Dragačević and Aneta Sabovljević ${ }^{1}$ \\ Institute of Botany and Garden, Faculty of Biology, University of Belgrade, Takovska 43, 11000 Belgrade, Serbia}

Additional index words. bryophytes, endangered, gametophyte multiplication, growth regulators, in vitro culture, morphogenesis in vitro, mosses

\begin{abstract}
This study provides the results of the developmental biology of the highly rare and endangered moss species Bruchia vogesiaca (recorded in less than 30 localities in the Northern Hemisphere, mainly western, central, and southwestern Europe). The aim of the study was to achieve the fully developed gametophyte and to propagate it for the purpose of conservation, reintroduction, and introduction to potential habitats free from xenic contamination. These gametophytes will be used for the study of genetics and genomics of this species. The micropropagation of $B$. vogesiaca was successfully applied on BCD medium supplemented with $0.1 \mu M$ BA and on BCD supplemented with $0.3 \mu M$ IBA and $0.3 \mu \mathrm{M}$ BA for numerous gametophore production. The highest production of secondary protonema was achieved on MS/2 S/2 medium enriched with 0.1 or $0.3 \mu M$ IBA and $0.3 \mu$ M BA. Rather successfully applied micropropagation of this threatened moss species enables better knowledge of its biology and is of great value for its conservation biology and developmental research. Chemical names used: indole-3butyric acid (IBA), N6-benzyladenine (BA), Murashige and Skoog medium (MS).
\end{abstract}

Culturing plant tissues and organs under axenic conditions was first established and profitably used in bryophytes (mosses, liverworts, and hornworts), especially mosses (Lal,

\footnotetext{
Received for publication 9 May 2012. Accepted for publication 20 July 2012.

The Serbian Ministry of Education and Science is acknowledged for support grants 173024 and 173030 and the Serbian-Hungarian Bilateral cooperation (TÉT_10-1-2011-0007) entitled “Ex situ conservation of rare and endangered bryophytes in Hungary, Serbia and Europe." J.G.S.-M. was supported by a Spanish Ministry of Science and Innovation "Ramón y Cajal" postdoctoral contract. We express our gratitude to Miss Maja Simić for her kind help in the laboratory.

${ }^{1}$ To whom reprint requests should be addressed; e-mail aneta@bio.bg.ac.rs, baneta@hotmail.com.
}

1984; Servettaz, 1913). Since then, comparatively little work has been carried out using bryophytes. Just a few mosses have been used to investigate the plant growth regulators influence on their development in vitro [e.g., Funaria hygrometrica Hedw. and Physcomitrella patens (Hedw.) Bruch \& Schimp., both from Funariales (Bijelović et al., 2004)]. Von Schwartzenberg (2009) reported bryophytes as interesting model systems in plant growth regulation research not only because they have simple organ structure, but also because they respond to many plant growth regulators. Not all tested bryophyte species react the same way to exogenously applied stimuli (i.e., growth regulators; Sabovljević et al., 2003; Vujičić et al., 2012). Mosses provide excellent and very convenient material for in vitro culture and they are very good experimental models for studies on basic molecular, cytological, and developmental plant biology (Duckett et al., 2004; Gonzales et al., 2006). However, axenic cultures of bryophytes are rather hard to establish and maintain (Sabovljević et al., 2003), especially those with unknown biology (Rowntree et al., 2011).

The moss Bruchia vogesiaca Schwägr. (Bruchiaceae) is recorded in the Northern Hemisphere (western Europe, North America, and China) in less than 30 localities (Weddeling et al., 2005). The distribution is rather fragmented and concentrated in the hilly belt of central, western, and southwestern Europe (like in southwest France; up to the alpine zone in more Atlantic situations, like in Portugal). Out of Europe, it has been collected few times in the United States: New York and New Hampshire (Rushing, 1986) and only once in China: Fujian (Cao and Gao, 1988) and none of these has been recently confirmed. B. vogesiaca is extremely rare in Europe. It is listed in national red lists and red data books as well as in the European level as an endangered species (European Committee for Conservation of Bryophytes, 1995) and it is reported in the annex II of the European Habitat directive. In Germany and Austria, it is considered as extinct (Grims and Köckinger, 1999; Ludwig et al., 1996), as vulnerable in Iberian Peninsula (Sérgio et al., 2006), and as endangered in France (Deperiers, 2000). Recently, it was newly recorded in England (Holyoak, 2007). Also, natural hybrids of female Bruchia vogesiaca $\times$ male Trematodon ambiguus (Hedw.) Hornschuch, another species of the bruchiaceae, were recorded in France (Frahm and Ho, 2010).

Bruchia vogesiaca inhabits the open wet edges of oligo-mesotrophic fens and moors as a shuttle species. Although the plants produce some sporophytes, the spores are rather too large for long-distance dispersal and probably water-dependent for spreading. Hugonnot et al. (2011) reported the difference in reproductive effort, i.e., less sporophyte production in some French populations, as a consequence of habitat destruction and pollution. All these are reasons for its high threat and rarity. Sites with such ecology become rarer everyday and active measures for protection are needed as proposed by Hugonnot et al. (2011) and Weddeling et al. (2005).

Bryophytes are often overlooked in conservation initiatives as diminutive, although some ex situ bryophyte collections exist (Rowntree, 2006; Rowntree et al., 2011). This is rather the result of their lower economical interest as well as the difficulty of establishing and maintaining stable in vitro cultures (Duckett et al., 2004; Sabovljević et al., 2003). Hence, protonemata can remain in early stages of development if specific exogenous physical and/or chemical factors are not involved. Such an inducing factor is not always easily to define, and if known, it is not easy to adjust the intensity and duration of its application (e.g., Bijelović et al., 2004; Sabovljević et al., 2005).

The aim of this study was to establish the in vitro culture of $B$. vogesiaca to examine its development under in vitro conditions, the 
ways for micropropagation of the species in ex situ conditions, i.e., large-scale production of viable gametophyte plants before attempts of reintroduction to nature, and introduction to potential natural and seminatural habitats. The other purpose of in vitro culture establishment is to use this plant for chemical analysis and further developmental studies, because clean moss material and especially of rare species is the starting point for its chemical content examination and pharmaceutical potential as well as genomic research (e.g., Bogdanović et al., 2011; Pejin et al., 2011, 2012; Sabovljević et al., 2010a, 2010b, 2011).

\section{Material and Methods}

Plant material. Taking into account that $B$. vogesiaca is a very rare and endangered species in Europe, plant material used for establishing the in vitro cultures was derived from herbarium vouchers. The material used was originally collected by M. Sabovljević in Department Haut-Saone in Vosge Mts. (France) on 10 June 2004 and deposited in the BEOU bryophyte collection under accession numbers 4137,4337 , and 4338 .

Establishment of gametophyte culture in vitro. In vitro cultures were initiated from sporophytes. The sporophytes (seven different out of three patches from the type locality) were cleaned and washed in running tap water followed by additional washes in doubledistilled water in a sterile area. They were then surface-disinfested with $10 \%$ sodium hypochlorite (commercial bleach) for $3 \mathrm{~min}$ and finally rinsed three times in sterile distilled water. Sterilized capsules were opened and the spores were spread on the growth medium. Half-strength MS medium (Murashige and Skoog, 1962) containing basal mineral salts and vitamins, $100 \mathrm{mg} \cdot \mathrm{L}^{-1}$ myo-inositol, sucrose $\left(15.0 \mathrm{~g} \cdot \mathrm{L}^{-1}\right)$, and solidified with $7.0 \mathrm{~g} \cdot \mathrm{L}^{-1}$ agar (Torlak purified, Belgrade) was used as a basal medium for the establishment of $B$. vogesiaca in in vitro culture. The $\mathrm{pH}$ of the media was adjusted to 5.8 before being autoclaved at $121^{\circ} \mathrm{C}$ for $25 \mathrm{~min}$. The plants obtained on primary protonema were used as start material for experimental treatments.

Optimization of micropropagation protocol. To study the effects of sucrose, basal medium, and growth regulators (auxin IBA and cytokinin BA) on the morphogenesis in terms of shoot induction and its multiplication and protonemal development, the following treatments were used: 1) half-strength MS medium without sucrose; 2) half-strength MS medium supplemented with $15.0 \mathrm{~g} \cdot \mathrm{L}^{-1}$ sucrose; and 3) BCD medium supplemented with $15.0 \mathrm{~g} \cdot \mathrm{L}^{-1}$ sucrose (see Sabovljević et al., 2009 for the medium details). For shoot induction, different concentrations $(0.01,0.03,0.1$, and $0.3 \mu \mathrm{M})$ of IBA and/or BA were used. Cultures were grown at $25 \pm 2{ }^{\circ} \mathrm{C}$ under a 16/8-h light/dark photoperiod at $47 \mu \mathrm{mol} \cdot \mathrm{m}^{-2} \cdot \mathrm{s}^{-1}$ photosynthetic photon flux density (provided by cool-white fluorescent tubes).

Data observations and statistical analysis. Per treatment 10 shoot explants $(5 \mathrm{~mm}$ high) were cultured in $90-\mathrm{mm}$ petri dishes. Four

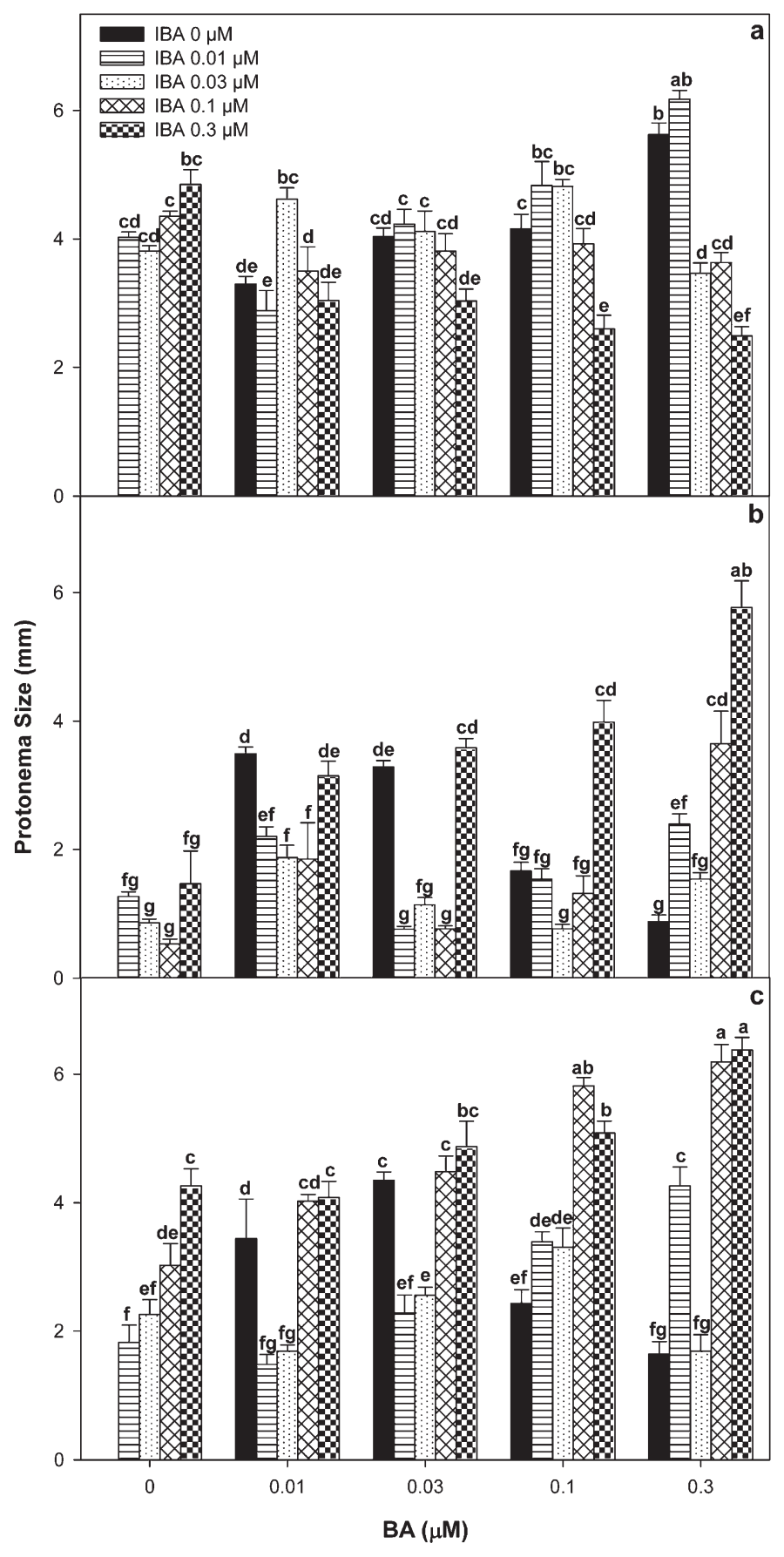

Fig. 1. Influence of different media types (BCD, MS/2, MS/2 S/2) and plant growth regulators (IBA and/or BA) on the size of Bruchia vogesiaca secondary protonema (mm) after 6 weeks culture. (A) BCD medium; (B) MS/2 medium; (C) MS/2 S/2 medium. Different letters above bars indicate significant differences among treatment according to least significant difference (LSD) test $\left(\operatorname{LSD}_{0.05}=11.74, P \leq\right.$ $0.05)$. MS $=$ Murashige and Skoog; IBA $=$ indole-3-butyric acid; $\mathrm{BA}=\mathrm{N}_{6}$-benzyladenine.

replicates of each treatment were conducted to account for the variance among culture plates. This experimental design was repeated twice. The performance of the explants in the different assayed culture media and growth regulators were evaluated by measuring the secondary protonemal development, new bud production, and the multiplication index. The multiplication index represents the number of newly grown shoots originating from newly induced buds on secondary protonema, which are derived from one starting shoot explant. All measurements were conducted on a light microscope Leica DMLS and a stereomicroscope Leica MZ75 (Leica Microsystems).

Data were analyzed through a factorial three-way analyses of variance followed by the separation of mean values by Fisher's least significant difference test. Statistics were considered significant at $P \leq 0.05$.

\section{Results and Discussion}

Secondary protonema did not develop in any of the assayed growing media without the supplement of growth regulators. Growth 
diameter of secondary protonema ranged from a minimum of $0.53 \mathrm{~mm}$ to a maximum of $6.37 \mathrm{~mm}$ in average in $\mathrm{MS} / 2$ medium with $0.1 \mu \mathrm{M}$ IBA and MS/2 S/2 enriched with $0.3 \mu \mathrm{M}$ of both IBA and BA growing media, respectively (Fig. 1B-C). The increase in IBA concentration in BCD medium up to $0.3 \mu \mathrm{M}$, in the absence of BA, resulted in the stimulation of secondary protonema growth. Similar results were obtained when the concentration of BA was increased in the absence of IBA in the BCD medium (Fig. 1A). These trends were not followed in $\mathrm{MS} / 2$ and $\mathrm{MS} / 2 \mathrm{~S} / 2$ growing media, where a clear growth pattern could not be defined. Some regularity in protonemal size increase can be noticed in both $\mathrm{MS} / 2$ and $\mathrm{MS} / 2 \mathrm{~S} / 2$ tested growth media with the highest concentration of IBA $(0.3 \mu \mathrm{M})$ combined with the BA increase (Fig. 1B-C).

The growth of secondary protonema was more positively affected by the simultaneous addition of IBA and BA in all assayed growing media (Fig. 1). The growth of secondary protonema was comparatively larger in media containing sucrose and supplemented with different concentration combinations of IBA and BA. Thus, in MS/2 S/2, the highest secondary protonema growth $(6.37 \mathrm{~mm}$ in average) was obtained when supplemented with $0.3 \mu \mathrm{M}$ each of IBA and BA followed by the supplement of this medium with $0.1 \mu \mathrm{M}$ IBA and $0.3 \mu \mathrm{M}$ BA ( $6.19 \mathrm{~mm}$ on average), both statistically supported. Similarly, good secondary protonema development was achieved on BCD medium supplemented with $0.01 \mu \mathrm{M}$ IBA and $0.3 \mu \mathrm{MBA}$ ( $6.17 \mathrm{~mm}$ on average) and on $\mathrm{MS} / 2$ supplemented each with $0.3 \mu \mathrm{M}$ IBA and BA (5.77 $\mathrm{mm}$ on average). Secondary protonema achieved the lower growth on sucrose-free MS/2 growing medium irrespective of the supplementation with growth regulators compared with the other two growing media, which contained sucrose $\left(15 \mathrm{~g} \cdot \mathrm{L}^{-1}\right)$ besides growth regulators. Exogenous supply of sucrose is obviously critical for protonema growth but is not essential for bud formation and development. The application of $0.3 \mu \mathrm{M}$ IBA and BA overcomes the growth inhibition on media lacking sucrose.

Bud development on secondary protonema of $B$. vogesiaca was achieved on $\mathrm{BCD}$ growing medium supplemented with both IBA and $\mathrm{BA}$, whereas on $\mathrm{MS} / 2$ growing medium, the buds developed either with this medium being supplemented with IBA or BA (Fig. 2). Bud development was totally unsuccessful on $\mathrm{MS} / 2 \mathrm{~S} / 2$ growing medium, irrespective of its supplementation with different concentrations of IBA, BA, or a combination of both growth regulators (data not presented). Numerous buds (135.67 buds on average) were developed on BCD growing medium supplemented with $0.1 \mu \mathrm{M}$ BA and in this same medium supplemented with $0.3 \mu \mathrm{M}$ of IBA and BA (132.83 on average) with non-significant differences between them. Leafy gametophores successfully developed into fully gametophyte plants on these BCD growing media, whereas on the other assayed growing media, gametophyte development was less abundant.

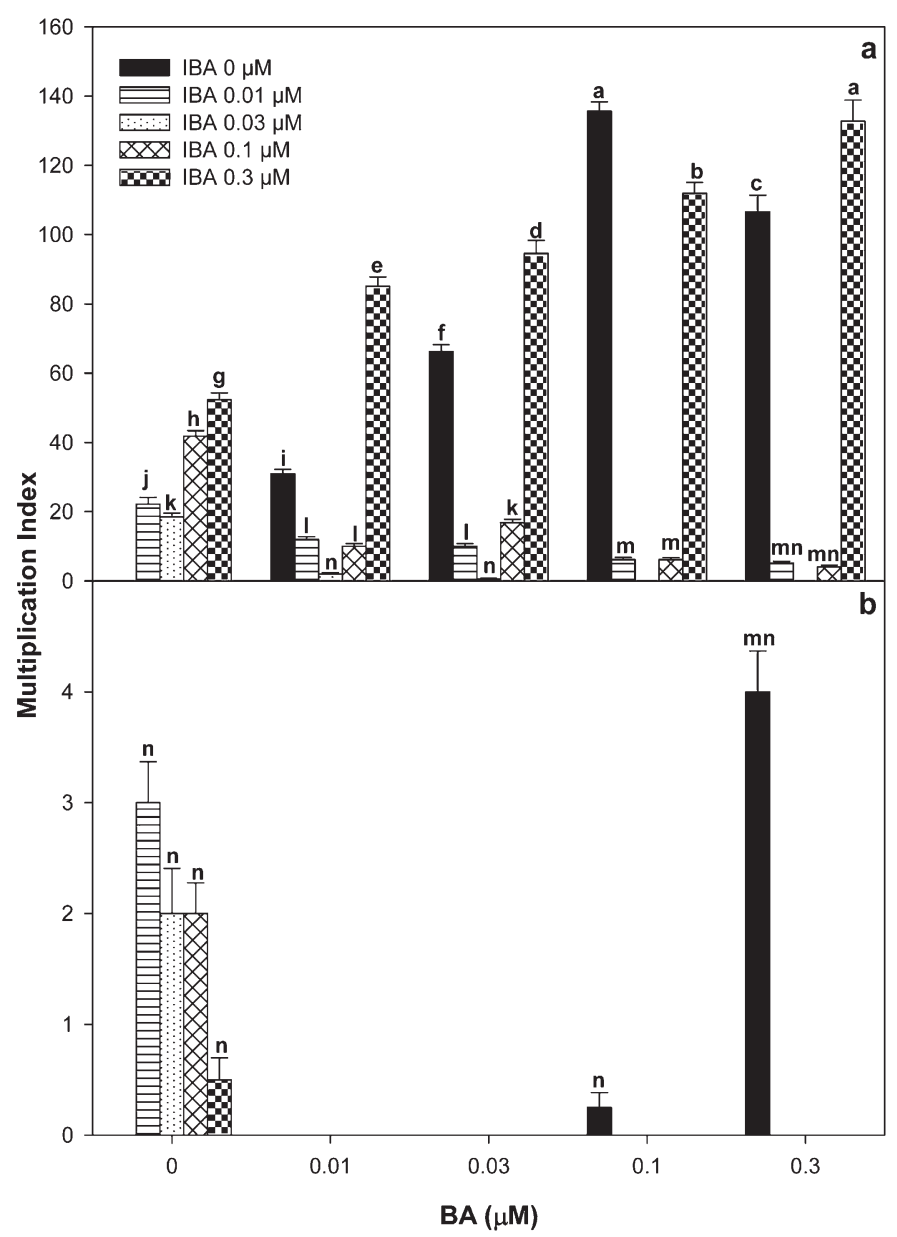

Fig. 2. Influence of different media types (BCD, MS/2) and plant growth regulators (IBA and/or BA) on in vitro multiplication of Bruchia vogesiaca after 6 weeks culture. (A) BCD medium; (B) MS/2 medium. Different letters above bars indicate significant differences among treatment according to least significant difference $(\mathrm{LSD})$ test $\left(\mathrm{LSD}_{0.05}=11.74, P \leq 0.05\right)$. MS = Murashige and Skoog; IBA = indole3-butyric acid; $\mathrm{BA}=\mathrm{N}_{6}$-benzyladenine.

Plants grown on the MS/2 medium had significantly lower index of multiplication. The highest multiplication index was obtained when $B$. vogesiaca was grown on $\mathrm{MS} / 2$ medium supplemented with only $0.3 \mu \mathrm{M}$ BA (Fig. 2B). Interestingly, when MS/2 was supplemented with sucrose, no bud production was observed, irrespective of the supplementation of $\mathrm{MS} / 2 \mathrm{~S} / 2$ with IBA, BA, or a combination of both growth regulators.

Auxins (such as IBA) and cytokinins (such as BA) are known to have basic functions in the regulation of normal bryophyte development. Previous investigations indicate that the hormonal status of mosses includes the sequential interaction of auxin and cytokinin as a main component (Bijelović et al., 2004; Bopp and Bhatla, 1985; Cove and Ashton, 1984). To date, the known effects of auxins on moss development include the inhibition of protonema growth, stimulation of rhizoid production, transformation of buds into filaments, torsion of young stems, the complete suppression of leaves on gametophores, and callus induction (Bopp, 1955). In B. vogesiaca in vitro culture, the increase in IBA concentration in BCD and $\mathrm{MS} / 2 \mathrm{~S} / 2$ medium increases protonema growth. The pattern of changes when BA is applied together with IBA is different. On $\mathrm{BCD}$ media containing BA in concentrations higher than $0.01 \mu \mathrm{M}$, the increase of IBA concentration decreases the growth of protonema. On MS/2 S/2 and MS/2 media when $\mathrm{BA}$ and IBA were applied together, protonema was largest when IBA was applied in the highest concentration $(0.3 \mu \mathrm{M})$, irrespective on BA concentration.

On the other hand, bud production, the number of buds, and their position along the caulonema and cell division in protonema are determined by cytokinins. Although the effects of exogenously applied auxins and cytokinins on moss development were discovered many years ago, results are very scattered and related to limited number of bryophyte species (namely Physcomitrella patens and Funaria hygrometrica). Because bryophytes are a very diverse group of plants, different bryophyte species are expected to show different responses to growth regulators and consequently, they should not be omitted from research on plant growth regulator performance and their influence on the morphogenesis of bryophyte organs.

To understand better the role of plant growth regulators, it is important to know 
more about their synthesis, metabolism, and transport. For this purpose, defective mutants have been introduced into bryophyte research. The defective mutants with a low degree of auxin production have been demonstrated to be relatively insensitive to exogenously supplied cytokinins (Schumaker and Dietrich, 1998). It can be concluded that sensitivity to cytokinins for bud production should be dependent on the presence of auxins, which should be present at higher concentrations (Cove and Ashton, 1984; Schumaker and Dietrich, 1998). However, as shown in this study, B. vogesiaca did not match the expected pattern. Our study highlights that speciesspecific research would be required to establish in vitro cultures successfully, because generally established rules may not apply to all the diversity of bryophytes.

The micropropagation of $B$. vogesiaca was successfully accomplished on BCD medium supplemented with $0.1 \mu \mathrm{M}$ BA and on treatment with $0.3 \mu \mathrm{M}$ of both BA and IBA when gametophore production is taken into account (Fig. 2A). On MS/2 S/2 medium supplemented with IBA $(0.1$ or $0.3 \mu \mathrm{M})$ and $0.3 \mu \mathrm{M} \mathrm{BA}$, the highest growth of secondary protonema was achieved. The protonemal and gametophore development were better achieved at conditions differing from those reported from other bryophyte species (e.g., Vujičić et al., 2012). Besides, this study shows that exogenous sucrose availability is essential for in vitro bryophyte development, at least at some stages of development of $B$. vogesiaca. However the mechanisms of such sucrose involvement still need to be clarified. This was previously demonstrated in two other unrelated moss species, Bryum argenteum and Atrichum undulatum (Sabovljević et al., 2005).

\section{Literature Cited}

Bijelović, A., M. Sabovljević, D. Grubišić, and R. Konjević. 2004. Phytohormone influence on the morphogenesis of two mosses [Bryum argenteum Hedw. and Atrichum undulatum (Hedw.) P. Beauv.]. Isr. J. Plant Sci. 52:31-36.

Bogdanović, M., M. Ilić, S. Zivković, A. Sabovljević, D. Grubišić, and M. Sabovljević. 2011. Comparative study on the effects of $\mathrm{NaCl}$ on selected moss and fern representatives. Aust. J. Bot. 59: 734-740.

Bopp, M. 1955. Die Entwicklung von Zelle und Kern im Protonema von Funaria hygrometrica Sibth. Planta 45:573-590.

Bopp, M. and S.C. Bhatla. 1985. Hormonal regulation of development in mosses, p. 65-87. In: Purohit, S.S. (ed.). Hormonal regulation of plant growth and development 2. Agro-Botanical Publishers, Old Ginanni, Bikaner.

Cao, T. and C. Gao. 1988. Studies on Chinese bryophytes (1). Bruchia Schwaegr. (Musci, Dicranaceae). J. Hattori Bot. Lab. 64:451-458.

Cove, D.J. and N.W. Ashton. 1984. The hormonal regulation of gametophytic development in bryophytes, p. 177-201. In: Dyer, A.F. and J.G. Duckett. (eds.). The experimental biology of bryophytes. Academic Press, London, UK.

Deperiers, S. 2000. Etude préalable à l'établissement du Livre Rouge des Bryophytes menaces de France métropolitaine. Ministère de l'environnement, D.N.P.-Laboratoire de phytogéographie, Caen, France. p. 1-176.

Duckett, J.G., J. Burch, P.W. Fletcher, H.W. Matcham, D.J. Read, A.J. Russel, and S. Pressel. 2004. In vitro cultivation of bryophytes: A review of practicalities, problems, progress and promise. J. Bryol. 26:3-20.

European Committee for Conservation of Bryophytes. 1995. Red data book of European bryophytes. ECCB, Trondheim, Norway.

Frahm, J.P. and B.-C. Ho. 2010. Discovery of a natural hybrid between Bruchia vogesiaca Schwägr. and Trematodon ambiguus (Hedw.) Hornsch. (Musci, Bruchiaceae). Cryptogam. Bryol. 31:95-99.

Gonzales, M.L., R. Mallon, J. Reinoso, and J. Rodrigues-Oubina. 2006. In vitro micropropagation and long-term conservation of the endangered moss Splachnum ampullaceum. Biol. Plant. 50:339-345.

Grims, F. and H. Köckinger. 1999. Rote Liste gefährdeter Laubmoose (Musci) Österreichs, 2. Fassung, p. 157-171. In: Niklfeld, H. (ed.). Rote Liste gefährdeter Pflanzen Österreichs, Wien (Austrai Medien Service), Austria.

Holyoak, D.T. 2007. Bruchia vogesiaca Schwaegr. (Bruchiaceae) on Bodmin moor, East Cornwall: A moss new to Britain. J. Bryol. 29:135-136.

Hugonnot, V., F. Bick, and A. Untereiner. 2011. Bruchia vogesiaca Schwaegr. en FranceRépartition, écologie et conservation d'une espèce anthropophile. Arch. Bryol. 91:1-16.

Lal, M. 1984. The culture of bryophytes including apogamy, apospory, parthenogenesis and protoplasts, p. 97-115. In: Dyer, A.F. and J.G. Duckett (eds.). The experimental biology of bryophytes. Academic Press, London, UK.

Ludwig, G., R. Düll, G. Philippi, M. Ahrens, S. Caspari, M. Koperski, S. Lütt, F. Schulz, and G. Schwab. 1996. Rote Liste der Moose (Anthocerophyta et Bryophyta) Deutschlands. Schriftenreihe für Vegetationskunde 28:189306.

Murashige, T. and F. Skoog. 1962. A revised medium for rapid growth and bioassays with tabacco tissue culture. Physiol. Plant. 15:473497.

Pejin, B., C. Iodice, G. Tommonaro, M. Sabovljević, A. Bianco, V. Tešević, V. Vajs, and S. De Rosa. 2012. Sugar composition of the moss Rhodobryum ontariense (Kindb.). Kindb. Nat. Prod. Res. 26:209-215.

Pejin, B., L. Vujisić, M. Sabovljević, V. Tešević, and V. Vajs. 2011. Preliminary data on essential oil composition of the moss Rhodobryum ontariense (Kindb.). Kindb. Cryptogam. Bryol. $32: 113-117$

Rowntree, J.K. 2006. Development of novel methods for the initiation of in vitro bryophyte cultures for conservation. Plant Cell Tiss. Org. 87:191-201

Rowntree, J.K., S. Pressel, M.M. Ramsay, A. Sabovljević, and M. Sabovljević. 2011. In vitro conservation of European bryophytes. In Vitro Cell. Dev. Biol. Plant 47:55-64.
Rushing, A.E. 1986. A revision of the genus Bruchia Schwaegr. J. Hattori Bot. Lab. 60:35-83.

Sabovljević, A., M. Sabovljević, and D. Grubišić. 2010a. Giberellin influence on the morphogenesis of the moss Bryum argenteum Hedw. in in vitro conditions. Arch. Biol. Sci. 62:373-380.

Sabovljević, A., M. Sabovljević, and V. Vukojević. 2010b. Effects of different cytokinins on chlorophyll retention in the moss Bryum argenteum (Bryaceae). Period. Biol. 112:301-305.

Sabovljević, A., M. Sabovljević, D. Grubišić, and R. Konjević. 2005. The effect of sugars on development of two moss species (Bryum argenteum and Atrichum undulatum) during in vitro culture. Belg. J. Bot. 138:79-84.

Sabovljević, A., M. Sabovljević, and N. Jocković. 2009. In vitro culture and secondary metabolite isolation in bryophytes, p. 117-128. In: Jain, S.M. and P.K. Saxena (eds.). Protocols for in vitro cultures and secondary metabolite analysis of aromatic and medicinal plants. Methods in molecular biology. Humana Press, c/o Springer Science+Business Media, New York.

Sabovljević, A., M. Soković, J. Glamočlija, A. Ćirić, M. Vujičić, B. Pejin, and M. Sabovljević. 2011. Bio-activities of extracts from some axenically farmed and naturally grown bryophytes. J. Med. Plants Res. 5:565-571.

Sabovljević, M., A. Bijelović, and I. Dragićević. 2003. In vitro culture of mosses: Aloina aloides (K.F. Schultz) Kindb., Brachythecium velutinum (Hedw.) B.S.\&G., Ceratodon purpureus (Hedw.) Brid., Eurhynchium praelongum (Hedw.) B.S.\&G. and Grimmia pulvinata (Hedw.). Sm. Turk. J. Bot. 27:441-446.

Schumaker, K.S. and M.A. Dietrich. 1998. Hormoneinduced signaling during moss development. Annu. Rev. Plant Physiol. Plant Mol. Biol. 49:501-523.

Sérgio, C., M. Burgués, R.M. Cros, C. Casas, and C. García. 2006. Red List and an updated checklist of bryophytes of the Iberian Peninsula (Portugal, Spain and Andorra). Lindbergia 31:109-126.

Servettaz, C. 1913. Reserches experimentales sur le development et la nutrition des mousses en milieux sterilise. Ann. Sci. Nat. Bot. Biol. Veg. 17:111-223.

Von Schwartzenberg, K. 2009. Hormonal regulation of development by auxin and cytokinin in moss, p. 246-281. In: Knight, C., P-F. Perroud, and D. Cove (eds.). Annual plant reviews. Vol. 36. The moss Physcomitrella patens. WileyBlackwell, UK.

Vujičić, M., A. Sabovljević, J. Šinžar-Sekulić, M. Skorić, and M. Sabovljević. 2012. In vitro development of the rare and endangered moss Molendoa hornschuchiana (Hook.) Lindb. ex Limpr. (Pottiaceae, Bryophyta). HortScience 47:84-87.

Weddeling, K., G. Ludwig, and M. Hachtel. 2005. Die Moose (Bryophyta, Marchantiophyta, Anthocerophyta) der FHH-Richtlinie, p. 215-220. In: Petersen, B., G. Ellwanger, G. Biewald, P. Boye, U. Hauke, G. Ludwig, P. Pretscher, E. Schroder, and A. Ssymank (eds.). Das europäische Schutzgenitssystem Natura 2000. Ökologie und Verbreitung von Arten der FHH-Richtlinie. Band I: Pflanzen und Wirbellose. Münster (Landwirtschaftsverlag). Schriftenreihe für Landschaftspflege und Naturschutz vol. 69, n. 1. Münster, Germany. 